\title{
The Effect of Carbon and Nitrogen Supplementation on Bacteriocin Production of Lactic Acid Bacteria from Pickled Yellow Bamboo Shoots (Dendrocalamus Asper)
}

\author{
LAKSMI HARTAJANIE*, LINDAYANI, AND LORENTIA SANTOSO \\ UNIKA Soegijapranata, Jalan Pawiyatan Luhur IV/1, Semarang 50234, Indonesia
}

\begin{abstract}
Six selected lactic acid bacteria (LAB) isolates from pickled Yellow Betung bamboo shoots were grown in the Mann Rogosa Sharpe-Broth (MRSB) media with different supplementation combination. The cell-free supernatant were evaluated for their ability to produce bacteriocin by adjusting its $\mathrm{pH}$ to 6.0 in order to remove organic acid effects. The bacteriocin activity was assayed by agar-well diffusion method. The inhibitory activity calculated in Activity Unit (AU in $\mathrm{mm}^{2} \mathrm{~mL}^{-1}$ ) of bacteriocins. The aims of this paper is to explore the effect of different medium compositions on bacteriocin production and its inhibitory activity against pathogenic bacteria (Listeria monocytogenes FNCC 0156, Staphylococcus aureus FNCC 0047, and Escherichia coli FNCC 0091). Supplementations of carbon and nitrogen sources induced production of bacteriocins. LAB isolates grown in media without supplementation could not produce bacteriocins. Growth of isolate D44 in the presence of $2 \%$ of glucose and $2 \%$ of yeast extract yielded the largest bacteriocin inhibitory activity levels of $3179 \mathrm{AU} \mathrm{mL}^{-1}$ against Listeria monocytogenes FNCC 0156, $4663 \mathrm{AU} \mathrm{mL}^{-1}$ against Staphylococcus aureus FNCC 0047, and $3109 \mathrm{AU}$ $\mathrm{mL}^{-1}$ against Escherichia coli FNCC 0091.
\end{abstract}

Key words: bacteriocin, lactic acid bacteria, pickled bamboo shoots, supplementation

Enam isolat bakteri asam laktat terpilih (LAB) yang diisolasi dari acar rebung bambu kuning ditumbuhkan di media Mann Rogosa Sharpe-Broth (MRSB) dengan kombinasi suplementasi yang berbeda. Supernatan bebas sel diatur $\mathrm{pH}$ menjadi 6,0 untuk menghilangkan efek asam organik dan dievaluasi aktivitas bakteriosinnya. Aktivitas bakteriosin diuji dengan metode difusi agar-well. Aktivitas penghambatan dihitung dalam Unit Aktivitas (AU dalam $\mathrm{mm}^{2} \mathrm{~mL}^{-1}$ ) bakteriosin. Tujuan dari penelitian ini adalah untuk mengeksplorasi pengaruh komposisi medium yang berbeda pada produksi bakteriosin dan aktivitas penghambatannya terhadap bakteri patogen (Listeria monocytogenes FNCC 0156, Staphylococcus aureus FNCC 0047, dan Escherichia coli FNCC 0091). Suplementasi sumber karbon dan nitrogen menginduksi produksi bakteriosin. Isolat LAB yang tumbuh di media tanpa suplementasi tidak dapat menghasilkan bakteriosin. Pertumbuhan isolat D44 dengan adanya 2\% glukosa dan $2 \%$ yeast extract menghasilkan aktivitas penghambatan bakteriosin terbesar, yaitu $3179 \mathrm{AU} \mathrm{mL}^{-1}$ terhadap Listeria monocytogenes FNCC 0156, $4663 \mathrm{AU} \mathrm{mL}^{-1}$ terhadap Staphylococcus aureus FNCC 0047, dan $3109 \mathrm{AU}$ $\mathrm{mL}^{-1}$ terhadap Escherichia coli FNCC 0091.

Kata kunci: acar rebung, bakteriosin, bakteri asam laktat, suplementasi

Bamboo shoots can be processed into fermented product such as vegetable pickle using lactic acid bacteria (LAB). LAB from different salt concentrations and temperatures have been isolated. Isolates were prepared from each fermentation conditions: fermentation in $2.5 \%$ salt solution at $15^{\circ} \mathrm{C}$ (21 isolates), $5.0 \%$ salt solution at $15{ }^{\circ} \mathrm{C}$ (22 isolates), $2.5 \%$ salt solution at $30^{\circ} \mathrm{C}$ (22 isolates), and $5.0 \%$ salt solution at $30^{\circ} \mathrm{C} \mathrm{(27} \mathrm{isolates).} \mathrm{All} \mathrm{combinations} \mathrm{of} \mathrm{salt}$ concentration and fermentation temperature yielded isolates with probiotic capability and antimicrobial activity (Lindayani et al. 2015).

Some lactic acid bacteria can produce bacteriocin (Salminen et al. 2004). Many studies conducted on bacteriocins found that the production of bacteriocin is

*Corresponding author: Phone: +62-24-8441555, Email: laksmi@unika.ac.id often regulated by some factors, such as growth $\mathrm{pH}$, temperature, and nutrient sources (Mahrous et al. 2013; Todorov and Dicks, 2005; Zhou et al. 2014). Bacteriocin production requires suitable culture medium containing all essential nutrients in suitable amounts. Growth medium compositions, especially the sources and concentrations of carbon and nitrogen strongly affect production of bacteriocins (Khay et al. 2013; Todorov and Dicks (2005).

The effect of medium compositions on the bacteriocin inhibitory activity of LAB isolated from fermented bamboo shoot pickle is still unknown. The aims of this paper are to to compare the effect of different medium compositions on bacteriocin production and its inhibitory activity against pathogenic bacteria (Listeria monocytogenes FNCC 0156, Staphylococcus aureus FNCC 0047, and Escherichia coli FNCC 0091). 


\section{MATERIALS AND METHODS}

Bacterial Strains and Culture Conditions. Eleven lactic acid bacteria (LAB) strains isolated from pickled yellow bamboo shoots (Lindayani et al. 2015; Hartayanie et al. 2016) were used in this study. The LAB were propagated in MRSB (Merck, Germany) containing $0.2 \%$ glucose (Merck, Germany) and incubated at $37{ }^{\circ} \mathrm{C}$ for $24 \mathrm{~h}$. The microorganisms were propagated and maintained in NB (Nutrient Broth) medium. Three indicator microorganisms used in antibacterial activity tests were Listeria monocytogenes FNCC 0156, Staphylococcus aureus FNCC 0047, and Escherichia coli FNCC 0091. The indicator microorganisms were propagated in Nutrient Broth (Merck, Germany) at $37^{\circ} \mathrm{C}$ for $24 \mathrm{~h}$.

Antibacterial Activity. Antibacterial activity was tested by using the well diffusion method (Ivanova et al. 2000). Ten $\mu \mathrm{L}$ of pathogen inocula equivalent to McFarland 3 was inoculated with $10 \mathrm{~mL}$ of nutrient agar (NA, Merck, Germany) as a pour plate and was allowed to solidify. Twenty $\mu \mathrm{L}$ of cell-free supernatant was inoculated in $5.5 \mathrm{~mm}$ diameter wells and incubated for $3 \mathrm{~h}$ at $4{ }^{\circ} \mathrm{C}$ to let it be absorbed. Sterile MRSB was used as a negative control. Antibacterial activity was tested against pathogenic bacteria (Staphylococcus aureus FNCC 0047 and Escherichia coli FNCC 0091). Clear zone around the wells was measured after $24 \mathrm{~h}$ incubation at $37^{\circ} \mathrm{C}$.

Antibacterial activity was expressed as arbitrary units (AU) per mL. One AU was defined as the reciprocal of the highest dilution showing a clear zone of growth inhibition. The calculation of the antibacterial activity was the same as the bacteriocin activity calculation.

Identification of Bacteriocin-Producing Species. The LAB was identified based on its physiological and biochemical characteristic using API 50 CHL test strips (Biomereux, Marcy-1'Etiole, France). The identified isolates were kept at $-18^{\circ} \mathrm{C}$ in MRS broth containing 15\% of glycerol (Merck, Germany).

Bacteriocin Bioassay. Bacteriocin activity testing was performed by using the well diffusion method (Ivanova et al. 2000). Ten $\mu \mathrm{L}$ of pathogen inocula equivalent to McFarland 3 was inoculated into $10 \mathrm{~mL}$ of nutrient agar (NA, Merck, Germany) as a pour plate and was allowed to solidify. Cell-free supernatant was neutralized by adjusting $\mathrm{pH}$ to 6.0 with $1 \mathrm{M} \mathrm{NaOH}$ in order to prevent the inhibitory effect of lactic acid (Karthikeyan and Santosh 2009). Twenty $\mu \mathrm{L}$ of neutralized cell-free supernatant was inoculated in 5.5 $\mathrm{mm}$ diameter wells and incubated for $3 \mathrm{~h}$ at $4{ }^{\circ} \mathrm{C}$ to let it absorbed. Sterile MRSB was used as a negative control. Bacteriocin activity was tested using pathogenic bacteria (Listeria monocytogenes FNCC 0156, Staphylococcus aureus FNCC 0047 and Escherichia coli FNCC 0091). The clear zone around the wells was measured after 24 hours incubation at $37^{\circ} \mathrm{C}$.

Bacteriocin activity was expressed as arbitrary units (AU) per mL. One AU was defined as the reciprocal of the highest dilution showing a clear zone of growth inhibition.

$$
\text { Bacteriocin activity }\left(\frac{\mathrm{mm}^{2}}{\mathrm{~mL}}\right)=\frac{\mathrm{Az}-\mathrm{As}}{\mathrm{V}}
$$

Key:

Az : Clear zone area $\left(\mathrm{mm}^{2}\right)$

As : Well area $\left(\mathrm{mm}^{2}\right)$

$\mathrm{V}$ : Sample volume $(\mathrm{mL})$

Effect of Medium Composition on Bacteriocin Production. The LAB isolates that have bacteriocin activity against pathogenic bacteria (Listeria monocytogenes FNCC 0156, Staphylococcus aureus FNCC 0047 and Escherichia coli FNCC 0091) were grown in MRSB at $37^{\circ} \mathrm{C}$ for $48 \mathrm{~h}$. The isolates adjusted to McFarland 5. Five hundreds $\mu \mathrm{L}$ of isolate was mixed with $500 \mu \mathrm{L}$ of the following media: (i) MRSB without supplementation; (ii) MRSB supplemented with $2 \%$ glucose; (iii) MRSB supplemented with 2\% glucose and 2\% tryptone; (iv) MRSB supplemented with 2\% glucose and 2\% yeast exctract; and (v) MRSB supplemented with $2 \%$ glucose, $1 \%$ tryptone, and $1 \%$ yeast extract. Then isolates were incubated in an incubator at $37^{\circ} \mathrm{C}$ for $24 \mathrm{~h}$. After incubation, the cells were separated by centrifugation at $11000 \mathrm{~g}$ for $10 \mathrm{~min}$ at $4{ }^{\circ} \mathrm{C}$. After centrifugation the supernatant was collected in a fresh sterile tube and the pellet was discarded. The cell free supernatant (CFS) was neutralized by adjusting $\mathrm{pH}$ to 6.0 using $1 \mathrm{~N} \mathrm{NaOH}$ for bacteriocin assays against three pathogenic bacteria (Listeria monocytogenes FNCC 0156, Staphylococcus aureus FNCC 0047 and Escherichia coli FNCC 0091).

\section{RESULTS}

All isolates that primarily confirmed as LAB from pickled Yellow Betung bamboo shoots were tested for antibacterial activity. The isolates showed antibacterial activity against Listeria monocytogenes FNCC 0156, Staphylococcus aureus FNCC 0047, and Escherichia coli FNCC 0091 (Table 1).

Different treatment in salt concentration and 
temperature of fermentation gave various LAB (Table 2). However, Leuconostoc mesenteroides ssp. cremoris was found from fermentation condition A (A43) and C (C18 and C29). Lactobacillus pentosus was found from fermentation condition B (B1) and D (D44). Isolates with significant values more than $80 \%$ showed very good identification results (A20, B1, B31, B32, C19, D11, D20, and D44). The results of API kit identification of A43, C18, and C29 could not be accepted because the significant value was less than 80\% (www.biomerieux-usa.com). Some rod-shaped isolates were acquired i.e., $\mathrm{B} 1$ as Lactobacillus pentosus (99.7\%), C19 as Lactobacillus plantarum (99.6\%) and D44 as Lactobacillus pentosus (96\%). Cocci-shaped were found from isolate A20, B3, and B32. A20 was identified as Leuconostoc mesenteroides ssp. mesenteroides/dextranicum 2 (96.8\%), B31 was identified as Enterococus durans (86.15\%) and B32 was identified as Lactococcus lactis ssp. lactis 1 (96.5\%).

Table 3 showed that there was no bacteriocin activity due to absence of supplementation. All isolates showed vary bacteriocin inhibitory activity against pathogen when they were grown in supplemented MRSB. C18 showed higher bacteriocin activity when it was cultured in MRSB supplemented with glucose and tryptone rather than in MRSB supplemented with glucose. Bacteriocin production of C19, C29, and D44 was improved by carbon and nitrogen supplementation. Tryptone was better supplement than yeast extract to improve bacteriocin production of $\mathrm{C} 19$. But on $\mathrm{C} 29$, yeast extract was better than tryptone. Bacteriocin production of D11 could only be induced by carbon supplementation.

Bacteriocin D44 could inhibit all pathogenic bacteria when produced in MRSB supplemented with combinations of carbon and nitrogen sources (tryptone

Table 1 Result of Antimicrobial Activity

\begin{tabular}{cccc}
\hline \multirow{2}{*}{$\begin{array}{c}\text { Fermentation } \\
\text { Condition }\end{array}$} & Isolate Code & \multicolumn{2}{c}{ Diameter of Inhibition Zone (mm) } \\
\cline { 3 - 4 } & & S. aureus FNCC 0047 & E. coli FNCC 0091 \\
\hline A & A20 & $9.70 \pm 1.21$ & $10.93 \pm 2.47$ \\
& A43 & $10.70 \pm 0.92$ & $9.67 \pm 1.81$ \\
B & B1 & $9.37 \pm 1.00$ & $9.50 \pm 1.73$ \\
& B31 & $12.40 \pm 0.00$ & $9.87 \pm 1.60$ \\
& B32 & $12.70 \pm 0.00$ & $8.27 \pm 1.10$ \\
C & C18 & $14.70 \pm 0.00$ & $8.90 \pm 0.00$ \\
& C19 & $10.70 \pm 0.00$ & $11.90 \pm 0.00$ \\
& C29 & $12.90 \pm 0.00$ & $9.80 \pm 0.00$ \\
D & D11 & $10.80 \pm 0.00$ & $10.80 \pm 0.00$ \\
& D20 & $10.73 \pm 2.06$ & $7.10 \pm 0.00$ \\
& D44 & $8.80 \pm 0.00$ & $10.90 \pm 0.00$ \\
\hline
\end{tabular}

Key:
$\mathrm{A}=2.5 \%$ of salt concentration at $15^{\circ} \mathrm{C}$
$\mathrm{B}=5.0 \%$ of salt concentration at $15^{\circ} \mathrm{C}$
$\mathrm{C}=2.5 \%$ of salt concentration at $30^{\circ} \mathrm{C}$
$\mathrm{D}=5.0 \%$ of salt concentration at $30^{\circ} \mathrm{C}$

Table 2 Result of API software identification (24 hours incubation)

\begin{tabular}{cccc}
\hline $\begin{array}{c}\text { Fermentation } \\
\text { Condition }\end{array}$ & $\begin{array}{c}\text { Isolate } \\
\text { Code }\end{array}$ & Species Identification & $\begin{array}{c}\text { Significant level } \\
\mathbf{( \% )}\end{array}$ \\
\hline \multirow{2}{*}{$\mathrm{A}$} & $\mathrm{A} 20$ & Leuconoctoc mesentroides ssp mesentroides/dextranicum 2 & $10.93 \pm 2.47$ \\
& $\mathrm{~A} 43^{*}$ & Leuconostoc mesentroides ssp cremoris & $9.67 \pm 1.81$ \\
& $\mathrm{~B} 1$ & Lactobacillus pentosus & $9.50 \pm 1.73$ \\
$\mathrm{~B}$ & $\mathrm{~B} 31$ & Enterococus durans & $9.87 \pm 1.60$ \\
& $\mathrm{~B} 32$ & Lactococcus lactis ssp lactis 1 & $8.27 \pm 1.10$ \\
& $\mathrm{C} 18^{*}$ & Leuconostoc mesentroides ssp cremoris & $8.90 \pm 0.00$ \\
$\mathrm{C}$ & $\mathrm{C} 19$ & Lactobacillus plantarum 1 & $11.90 \pm 0.00$ \\
& $\mathrm{C} 29^{*}$ & Leuconostoc mesentroides ssp cremoris & $9.80 \pm 0.00$ \\
& $\mathrm{D} 11$ & Lactobacillus fermentum 1 & $10.80 \pm 0.00$ \\
$\mathrm{D}$ & $\mathrm{D} 20$ & Lactobacillu s plantarum & $7.10 \pm 0.00$ \\
& $\mathrm{D} 44$ & Lactobacillus pentosus & $10.90 \pm 0.00$ \\
\hline
\end{tabular}

Key:

$$
\begin{aligned}
& *=\text { Significant }<80 \% \\
& \mathrm{~A}=2.5 \% \text { of salt concentration at } 15^{\circ} \mathrm{C} \\
& \mathrm{B}=5.0 \% \text { of salt concentration at } 15^{\circ} \mathrm{C} \\
& \mathrm{C}=2.5 \% \text { of salt concentration at } 30^{\circ} \mathrm{C} \\
& \mathrm{D}=5.0 \% \text { of salt concentration at } 15^{\circ} \mathrm{C}
\end{aligned}
$$


Table 3 Effect of adding some nutrient components in MRS-B medium on bacteriocin Inhibitory activity $\left(A U \mathrm{~mm}^{2} \mathrm{~mL}^{-1}\right)$ by $\mathrm{LAB}$ isolates which isolated from yellow betung bamboo shoot pickle (C and D)

\begin{tabular}{|c|c|c|c|c|c|c|c|}
\hline \multirow[b]{3}{*}{$\begin{array}{l}\text { LAB } \\
\text { Isolate }\end{array}$} & \multirow[b]{3}{*}{$\begin{array}{c}\text { Pathogenic } \\
\text { Bacteria }\end{array}$} & \multicolumn{6}{|c|}{ Activity Unit of Bacterio cins $\left(\mathrm{mm}^{2} \mathrm{~mL}^{-1}\right)$} \\
\hline & & \multicolumn{6}{|c|}{ Medium Compositions of Bacteriocin Production } \\
\hline & & MRS-B & & $\begin{array}{l}\text { MRS-B } \\
\text { supplemented } \\
\text { with glucose }\end{array}$ & $\begin{array}{l}\text { MRS-B } \\
\text { supplemented } \\
\text { with glucose } \\
\text { and tryptone }\end{array}$ & $\begin{array}{l}\text { MRS-B } \\
\text { supplemented } \\
\text { with glucose } \\
\text { and yeast } \\
\text { extract }\end{array}$ & $\begin{array}{l}\text { MRS-B } \\
\text { supplemented } \\
\text { with glucose, } \\
\text { tryptone, and } \\
\text { yeast extract }\end{array}$ \\
\hline \multirow[t]{3}{*}{$\mathrm{C} 18$} & 1 & & - & 323 & 831 & 537 & 226 \\
\hline & 2 & & - & 867 & 1061 & 353 & - \\
\hline & 3 & & - & 394 & 750 & - & 337 \\
\hline \multirow{3}{*}{$\mathrm{C} 19$} & 1 & & - & - & 173 & - & - \\
\hline & 2 & & - & - & 337 & - & - \\
\hline & 3 & & - & - & 415 & - & - \\
\hline \multirow[t]{3}{*}{$\mathrm{C} 29$} & 1 & & - & - & - & 173 & - \\
\hline & 2 & & - & - & - & 293 & - \\
\hline & 3 & & - & - & - & 517 & - \\
\hline \multirow[t]{3}{*}{ D11 } & 1 & & - & 1815 & - & - & - \\
\hline & 2 & & - & 2704 & - & 142 & - \\
\hline & 3 & & - & 2575 & - & - & - \\
\hline \multirow[t]{3}{*}{ D20 } & 1 & & - & - & - & - & - \\
\hline & 2 & & - & 173 & 208 & - & - \\
\hline & 3 & & - & 94 & 77 & - & 0 \\
\hline \multirow[t]{3}{*}{ D44 } & 1 & & - & - & 113 & 3179 & 795 \\
\hline & 2 & & - & 100 & 265 & 4663 & 3250 \\
\hline & 3 & & - & - & 245 & 3109 & 1558 \\
\hline
\end{tabular}

Key: $1=$ L.monocytogenes $($ FNCC 0156); 2 = S.aureus $($ FNCC 0047); $3=$ E.coli $($ FNCC 0091) - = isolates showed no bacteriocin inhibitory activity against pathogenic bacteria

or yeast extract or a combination both of them). It had a broader zone of inhibition against pathogenic bacteria than other bacteriocins used in this study (Fig 1). The presence of $2 \%$ of glucose and $2 \%$ of yeast extract resulted in the largest bacteriocin inhibitory activity levels of $3179 \mathrm{AU} \mathrm{mL}^{-1}$ against Listeria monocytogenes FNCC 0156, $4663 \mathrm{AU} \mathrm{mL}^{-1}$ against Staphylococcus aureus FNCC 0047, and $3109 \mathrm{AU}^{-1}$ against Escherichia coli FNCC 0091 (Table 3 dan Fig 2).

LAB isolates had different response for each treatment of supplementations as shown on table 3 . Carbon and nitrogen supplementation gave different response to induce bacteriocin inhibitory activity against Listeria monocytogenes FNCC 0156, Staphylococcus aureus FNCC 0047, and Escherichia coli FNCC 0091. Bacteriocin from isolate D44 showed the largest inhibitory activity against pathogens when it was grown in MRSB supplemented with $2 \%$ glucose and $2 \%$ yeast extract. Each isolate had different result on bacteriocin inhibitory activity for each supplementation. AU of $3179 \mathrm{~mm}^{2} \mathrm{~mL}^{-1}$ against Listeria monocytogenes FNCC 0156, $4663 \mathrm{~mm}^{2} \mathrm{~mL}^{-1}$ against Staphylococcus aureus FNCC 0047, and $3109 \mathrm{~mm}^{2} \mathrm{~mL}^{-1}$ against Escherichia coli FNCC 0091. Compared to the other tested pathogenic bacteria, the impact of this bacteriocin was less against Escherichia coli FNCC 0091 and Listeria monocytogenes FNCC 0156.

\section{DISCUSSION}

The inhibitory effect of LAB isolates may be due to the production of several antimicrobial compounds (Sifour et al. 2012). Different temperatures of fermentation may affect the potential of $L A B$ in producing bacteriocins. Higher temperature altered the fermentation to homofermentative (Harris, 1998 in Salminen et al. 2004). Since the fermentation type of Lactobacillus pentosus is homofermentative (Fleming 1991 in Salminen et al. 2004), higher temperature (fermentation condition D) could be a better condition for the growth of Lactobacillus pentosus than fermentation condition B. Indirectly, maximum growth of Lactobacillus pentosus may affect its potential to produce bacteriocins. Leuconostoc mesenteroides belonged to heterofermentative bacteria showed a better bacteriocin inhibitory activity when isolated from higher temperature of fermentation (Fleming 1991 in Salminen et al. 2004).

Tryptone and yeast extract contain various amino acid which can help to increase the biomass (Salminen et al. 2004). The inhibition activity of bacteriocin against pathogens depends on nutrient addition (Table 3). Specific nutrients are required to improve bacteriocin production (Todorov and Dicks 2005b). Bacteriocins were only produced when nutrients were 


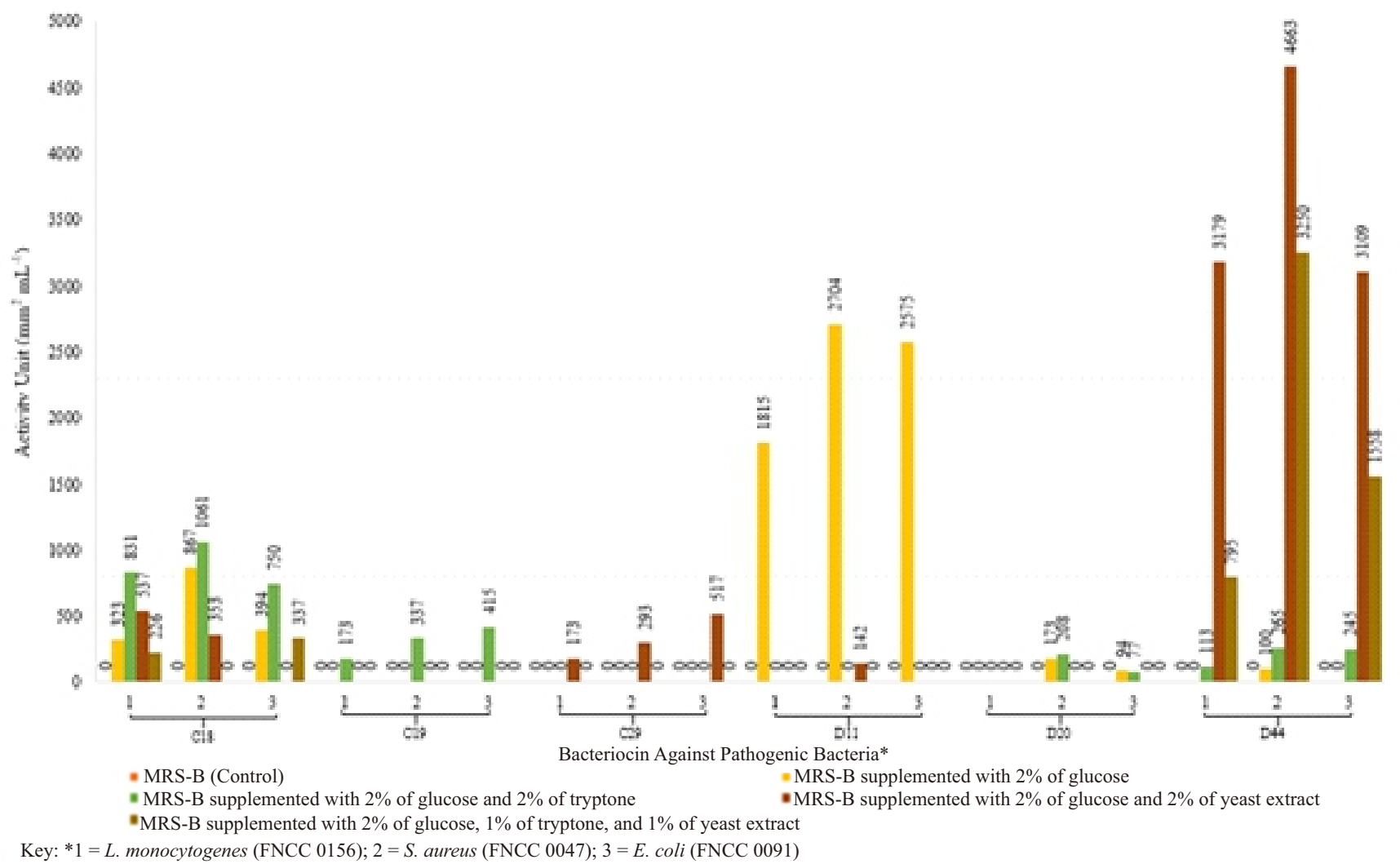

Fig 1 Effect of medium compositions on bacteriocin inhibitory activity $\left(\mathrm{AU} \mathrm{mm} \mathrm{mL}^{-1}\right)$ of $\mathrm{C}$ and $\mathrm{D}$ isolates against L. monocytogenes (FNCC 0156), S. aureus (FNCC 0047), and E.coli (FNCC 0091).
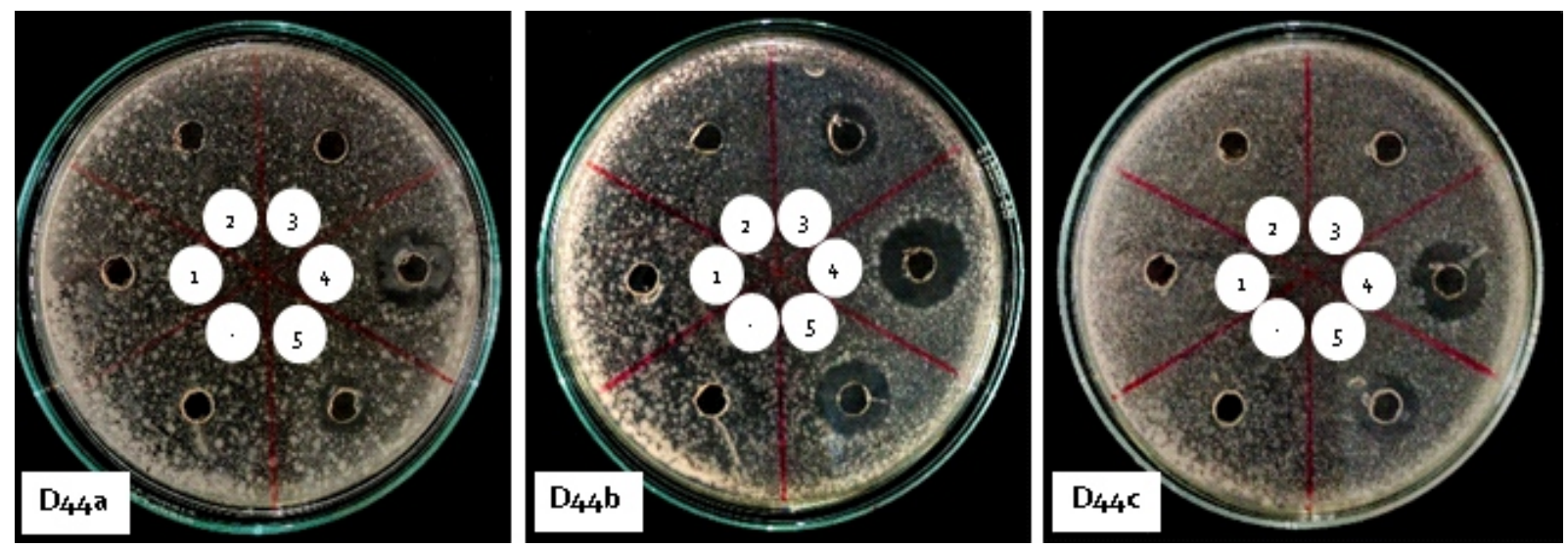

Fig 2 Effect of medium compositions on bacteriocin D44 inhibitory activity test using agar-well diffusion method against L. monocytogenes (FNCC 0156) (A), S. aureus (FNCC 0047) and E. coli (FNCC 0091) (C) ; Negative control (-) MRS-B (1) MRS-B supplemented with 2\% of glucose (2) MRS-B supplemented with $2 \%$ of glucose and $2 \%$ of tryptone (3) MRS-B supplemented with $2 \%$ of glucose and $2 \%$ of yeast extract (4) MRS-B supplemented with $2 \%$ of glucose, $1 \%$ of tryptone and $1 \%$ of yeast extract $(5)$.

available during the incubation period. It has been proved that the composition of the growth medium is very important for the production of individual bacteriocins (Todorov and Dicks 2005b).

Yeast extract is a rich source of vitamin and provides excellent growth conditions for more microorganisms. It is probable that the yeast extract may take a part in deactivation of an inhibitor of bacteriocin synthesis (Fukushima et al. 1983). It was observed that all bacteriocins had different inhibitory effect on Listeria monocytogenes FNCC 0156, Staphylococcus aureus FNCC 0047, and Escherichia coli FNCC 0091. Surprisingly, the same LAB species from different fermentation conditions had different bacteriocin inhibitory activity (Table 1).

Some bacteriocins inhibited not only pathogenic 
but also Gram-positive and Gram-negative in general. Bacteriocins are ribosomally synthesized compounds produced by bacteria in order to inhibit the growth of other bacteria. Bacteriocins have a narrow killing spectrum and thus they are generally able to kill only bacteria closely related to the producing strain (Cleveland et al. 2001 in Salminen et al. 2004). Moreover, Gram-negative bacteria was mostly resistant to the bacteriocins of LAB. Bacteriocin produced by Lactococcus lactis KCA2386 and plantaricin $35 \mathrm{~d}$ produced by Lactobacillus plantarum had inhibitory activity against Gram-negative bacteria (Ivanova et al. 2000). This is quite different from most of the bacteriocins which inhibit only closely related strains (Hata et al. 2010).

Inhibitory effects of bacteriocin on tested bacteria vary (Table 3 ). The differences between the inhibition zone against each pathogenic bacteria associated with the components of the cell structure. Inhibition mechanism by antibacterial compounds is by destroying the bacterial cell wall. The response of LAB in damaging the peptidoglycan component is stronger on neighbor cells (Gram-positive bacteria). Lipopolysaccharide (LPS) layer on Gram-negative bacteria cells can interfere the ability of bacteriocin to inhibit Gram-negative pathogenic bacteria. Some exceptions were found, bacteriocin of C19 and C29 had a broader inhibitory activity against Escherichia coli FNCC 0091 than Staphylococcus aureus FNCC 0047 and Listeria monocytogenes FNCC 0156. This exceptions could have occured because of original growth condition of isolates and bacteriocin diffusion on agar-media.

In conclusion, carbon and nitrogen supplemention were able to induce the production of bacteriocin in some LAB. Bacteriocin of LAB from pickled Yellow Betung bamboo shoots shows inhibition towards Listeria monocytogenes FNCC 0156, Staphylococcus aureus FNCC 0047, and Escherichia coli FNCC 0091.

\section{ACKNOWLEDGMENT}

This work was supported by a grant from Directorate General of Indonesian Higher Education. This research a part of the second year of Penelitian Unggulan Perguruan Tinggi (PUPT) 2016/2017 entitled "Efek Probiotik dan Mikrostatik dari Bakteri Asam Laktat yang Berperan dalam Fermentasi Acar Rebung", grant number 011/K6/KM/SP2H/RISET TERAPAN/2016.

\section{REFERENCES}

Aasen IM, Møretrø T, Katla T, Axelsson L, Storro I. 2000. Influence of complex nutrients, temperature and $\mathrm{pH}$ on bacteriocins production by Lactobacillcus sakei CCUG 42687. J Appl Microbiol Biotechnol. 53(2):159-166. doi: $10.1007 / \mathrm{s} 002530050003$.

Atlas RM. 2006. $2^{\text {nd }}$ Handbook of microbiological media for the examination of food. Taylor and Francis Group.

Chen H, Hoover DG. 2003. Bacteriocins and their food applications. Comp Rev Food Sci Food Safety. 2:82-100. doi: 10.1111/j.1541-4337.2003.tb00016.x.

Chouwdhury D, Sahu JK, Sharma GD. 2012. Bamboo shoot: microbiology, biochemistry and technology of fermentation. a review. Indian $\mathrm{J}$ Tradit Know. 11(2):242-249.

Cleveland J, Montville TJ, Nes IF, Chikindas L. 2001. Bacteriocins: safe, natural antimicrobials for food preservation. Int J Food Microbiol. 71(1):1-20.

Con AH, Karasu N. 2009. Determination of antagonistic starter cultures for pickle and olive fermentation process. Czech J Food Sci. 27 (3): 185-193.

Cotter P, Hill DC, Ross RP. 2005. Bacteriocins: developing innate immunity for food. Nat Rev Microbiol. 3(10):777-788. doi: 10.1038/nrmicro1273.

Deraz, SF, Karlsson EN, Hedstrom M, Andersson MM, Mattiasson B. 2005. Purification and characterization of acidocin D20079, a bacteriocin produced by Lactobacillus acidophilus DSM 20079. J Biotechnol. 117(4):343-354. doi: 10.1016/j.jbiotec.2005.02.005.

Eddleman H. 1999. www.disknet.com/indiana_biolab/. (Accessed on February22 2016; 07:15 p.m.).

Enan G, el-Essawy AA, Uyttendaele M, Debevere J. 1996. Antibacterial activity of Lactobacillus plantarum UG1 isolated from dry sausage: characterization, production and bactericidal action of Plantaricin UG1. Int J Food Microbiol. 30(3):189-215. doi: 10.1016/01681605(96)00947-6.

Ennahar K, Sonomoto, Ishizaki A. 1999. Class IIa bacteriocins from lactic acid bacteria: antibacterial activity and food preservation. J Biosci Bioeng. 87(6):705-716. doi: 10.1016/S1389-1723(99)80142$\mathrm{X}$.

Fukushima H, Kelstrup J, Fukushima S, Umemoto T, Sagawa H. 1983. Isolation, partial purification and preliminary characterization of a bacteriocin from Streptococcus mutants Rm-10. Antonie van Leeuwenhoek. 49:41-50. doi: 10.1007/BF00457878.

Hartayanie L, Lindayani, Palupi MP. 2016. Antimicrobial activity of lactic acid bacteria from bamboo shoot pickles fermented at $15 \mathrm{C}$. Microbiol Indones. 
10(2):71-77. doi: 10.5454/mi.10.2.5.

Han B, Yu Z, Liu B, Ma Q, Zhang R. 2011. Optimization of bacteriocin production by Lactobacillus plantarum YJG, isolated from the mucosa of the gut of healthy chickens. African J Microbiol Res. 5(10):1147-1155. doi: 10.5897/AJMR10.643.

Hata T, Tanaka R, Ohmono S. 2010. Isolation and characterization of Plantaricin ASM1: a new bacteriocin produced by Lactobacillus plantarum A-1. Int J Food Microbiol. Vol 137: 94-99. doi: 10.1016/j.ijfoodmicro.2009.10.021.

Hutkins RW. 2006. Microbiology and technology of fermented foods. Blackwell Publishing Ltd.

Iranmanesh M, Ezzatpanah H, Mojgani N, Mak T. 2015. Characterization and kinetics of growth of bacteriocin like substance produced by lactic acid bacteria isolated from ewe milk and traditional sour buttermilk in Iran. J Food Process Technol. 6(12):529-534. doi: 10.4172/2157-7110.1000529.

Ivanova I, Kabadjova P, Pantev A, Danova S, Dousset X. 2000. Detection, purification and partial characterization of a novel bacteriocin substance produced by Lactoccous lactis subsp. lactis B14 isolated from Boza-Bulgarian traditional cereal beverage. Biocatalysis: Fundamentals and Applications. 41(6):47-53.

Karthiyekan V, Santosh SW. 2009. Isolation and partial characterization of bacteriocin produced from Lactobacillus plantarum. Afr J Microbiol Res. 3(5):233-239.

Kelly WJ, Asmudson RV, Huang CM. 1996. Characterization of Plantaricin KW30, a bacteriocin produced by Lactobacillus plantarum. J Appl Bacteriol. 81:657-662. doi: 10.1111/j.13652672.1996.tb03561.

Lee H, Yoon H, Ji Y. 2011. Functional properties of Lactobacillus strains isolated from kimchi. Int J Food Microbiol.145:155-161. doi: 10.1016/j.ijfoodmicro. 2010.12.003.

Lindayani, Hartajanie L, Murniati MP. 2015. Efek probiotik dan mikrostatik dari bakteri asam laktat yang berperan dalam fermentasi acar rebung. Penelitian Unggulan Perguruan Tinggi. Universitas Katolik Soegijapranata, Semarang.

Mahrous H, Abeer M , A bd El-Mongy M, El-Batal AI, Hamza HA. 2013. Study bacteriocin production and optimization using new isolates of Lactobacillus spp. isolated from some dairy products under different culture conditions. Food Nutr Sci. 4:342-356. doi: 10.4236/fns.2013.43045

Mohankumar A, Murugalatha N. 2011. Characterization and antibacterial activity of bacteriocin producing Lactobacillus isolated from raw cattle milk sample. Int
J Biol. 3(3):128-143. doi: 10.5539/ijb.v3n3p12.

Nithya K, Senbagam D, Senthilkumar B, Udhayashree N, Gurusamy R. 2012. Characterization of bacteriocin producing lactic acid bacteria and its application as food preservative. Afr J Microbiol Res. 6(6):11381146. doi: 10.5897/AJMR11.1214.

Ooi MF, Mazlan N, Foo HL, Loh TC, Mohamad R, Rahim RA, Ariff A. 2015. Effect of carbon and nitrogen sources on bacteriocin-inhibitory activity of postbiotic metabolites produced by Lactibacillus plantarum IUL4. Malays J Microbiol. 11(2):176-184. doi: $10.21161 / \mathrm{mjm} .13014$.

Pandey AK, Ojha V, Choubey SK. 2012. Development and shelf-life evaluation of value added edible products from bamboo shoot. American J. Food Tech.7(6): 363371. doi: 10.3923/ajft.2012.363.371.

Parada JL, Caron CR, Medeiros ABP, Soccol CR. 2007. Bacteriocins from lactic acid bacteria: purification, properties and use as biopreservatives. Int J Braz Arch Biol Technol. 50(3):521-542. doi: 10.1590/S151689132007000300018 .

Salminen, S, Wright AV, Ouwehand A. 2004. Lactic acid bacteria: microbiological and functional aspects $3^{\text {rd }}$ edition. Marcell Dekker Inc.

Sifour M, Tayeb I, Haddar HO, Namous H, Aissaoui S. 2012. Production and characterization of bacteriocin of Lactobacillus plantarum F12 with inhibitory activity against Listeria monocytogenes. Online J Sci Technol. Vol2(1):55-61.

Elayaraja S, Annamalai M, Mayavu P, Balasubramanian T. 2014. Production, purification and characterization of bacteriocin from Lactobacillus murinus AU06 and its broad antibacterial spectrum. Asian Pac J Trop Biomed. 4(Suppl 1):S305-11. doi: 10.12980/APJTB.4.2014C537.

Soomro AH, Masud T, Anwar K. 2002. Role of lactic acid bacteria $(\mathrm{LAB})$ in food preservation and human health. Pak J Nutr. 1(1):20-24. doi: 10.3923/pjn.2002.20.24.

Tagg JR, Dajani AS, Wannamaker LW. 1976. Bacteriocins of gram-positive bacteria. Bacteriol Rev. 40(3):722-756.

Thirumurugan A, Ramachandran S, Gobikrishnan S. 2015. Optimization of medium components for maximizing the bacteriocin production by Lactobacillus plantarum ATM11 using statistical design. Int Food Res J. 22(3):1272-1279.

Todorov SD, Dicks LMT. 2007. Bacteriocin production by Lactobacillus pentosusST712BZ isolated from boza. Braz J Microbiol. 38(1). doi: 10.1590/S151783822007000100034 .

Todorov SD, Dicks LMT. 2006. Effect of medium components on bacteriocin production by Lactobacillus plantarum strains ST23LD and ST341LD, isolated from spoiled olive brine. J Microbiol Res. 161:102-108. doi: 10.1016/j.micres.2005.06.006. 
Todorov SD, Dicks LMT. 2005a. Growth parameters influencing the production of Lactobacillus rhamnosus bacteriocins ST461BZ and ST462BZ. J Microbiol. 55(4):283-289.

Todorov SD, Dicks LMT. 2005b. Effect of growth medium on bacteriocin production by Lactobacillus plantarum ST194BZ, a strain isolated from boza. Food Tech Biotechnol J. 43(2):165-173.

www.biomerieux-usa.com. (Accessed on February 24
2016; 08:00 p.m.).

www.fda.gov/Food/ScienceResearch/LaboratoryMetho ds/BacteriologicalAnalyticalmanualBAM/default.h tm. (Accessed on January 22 2016; 12:58 p.m.).

Zhou F, Zhao H, Bai F, Dziugan P, Liu Y, Zhang B. 2014. Purification and characterization of the bacteriocin produced by Lactobacillus plantarum, isolated from chinese pickle. J Food Sci. 32(5):430-436. 